\author{
Indonesia Journal of Learning Education and Counseling \\ Website: https://journal.ilininstitute.com/index.php/IJoLEC \\ Vol 3, No 2, 2021, pp 148-155 \\ p-ISSN:2622-8068 dan e-ISSN: 2622-8076
}

\title{
Pengembangan Multimedia Interaktif dalam Pembelajaran Simulasi dan Komunikasi Digital
}

\author{
Handy Ferdiansyah ${ }^{1}$, Abdul Haling ${ }^{2}$, Nurhikmah $\mathbf{H}^{3}$ \\ ${ }^{123}$ Teknologi Pendidikan, Program Pascasarjana, Universitas Negeri Makassar \\ 1Email: handyferdiansyah888@gmail.com
}

\begin{tabular}{l}
\hline \multicolumn{1}{c}{ Artikel info } \\
\hline \\
Artikel history: \\
Received: $15-11-2020$ \\
Revised: $20-12-2020$ \\
Accepted: $10-03-2021$ \\
Publish: $21-03-2021$ \\
\\
DOI: \\
doi.org/10.31960/ ijolec. \\
v3i2.879
\end{tabular}

Abstract. This research aims, (1) to know the description of the need for interactive multimedia development, (2) the validity, (3) practicality, and (4) the effectiveness of interactive multimedia products in learning simulation and digital communication. This research is a research and development $(\mathrm{R} \& \mathrm{D})$ using the ADDIE development model with the subject of research as a material expert, a media expert, subject teacher, and forty students. Data was collected by interviews, questionnaires, and tests. The data obtained in this study are qualitative and quantitative data. The results of research are: (1) The level of need for interactive multimedia in learning learning simulation and digital communication for $10^{\text {th }}$ grade student at SMK Muhammadiyah Sidenreng Rappang is very high. This is evidenced by the value of student learning outcomes that have reached the minimum completeness criteria after using interactive multimedia. (2) The results of the product validation data analysis are in the very valid category, this is obtained from the validation assessment of material and media experts. (3) The results of the respondents' evaluation of small group trials and teacher responses to interactive multimedia products are stated to be very practical. (3) Interactive multimedia in simulation learning and digital communication developed effectively as seen from the average recapitulation of learning outcomes assessment shows an increase in learning scores of all students is above the minimal completeness criteria value.

\begin{abstract}
Abstrak. Penelitian ini bertujuan, (1) untuk mengetahui gambaran kebutuhan pengembangan multimedia interaktif, (2) kevalidan, (3) kepraktisan, dan (4) keefektifan produk multimedia interaktif dalam pembelajaran simulasi dan komunikasi digital. Penelitian ini merupakan penelitian dan pengembangan (R\&D) dengan menggunakan model pengembangan ADDIE dengan subjek penelitian seorang ahli materi, seorang ahli media, guru mata pelajaran, dan empat puluh siswa. Pengumpulan data dilakukan dengan cara wawancara, angket, dan tes. Data yang diperoleh dalam penelitian ini adalah data kualitatif dan kuantitatif. Hasil penelitian yaitu: (1) Tingkat kebutuhan akan multimedia interaktif dalam pembelajaran simulasi dan komunikasi digital kelas X di SMK Muhammadiyah Sidenreng Rappang sangat tinggi. Hal tersebut dibuktikan dengan nilai hasil belajar siswa yang telah mencapai kriteria ketuntasan minimal setelah menggunakan
\end{abstract}


multimedia interaktif. (2) Hasil analisis data validasi berada pada kategori sangat valid, ini diperoleh dari penilaian validasi ahli materi dan media. (3) Hasil penilaian responden uji coba kelompok kecil dan tanggapan guru terhadap produk multimedia interaktif dinyatakan sangat praktis. (3) Multimedia interaktif dalam pembelajaran simulasi dan komunikasi digital yang dikembangkan efektif dilihat dari rata-rata rekapitulasi hasil belajar menunjukakan adanya peningkatan skor tes belajar seluruh siswa sudah di atas nilai kriteria ketuntasan minimal.

\section{Keywords:}

multimedia

interaktif;

simulasi;

komunikasi

digital;
Coresponden author:

Jalan: Andi DJemma, Makassar

Email:handyferdiansyah888@gmail.com

(a) $\mathbb{P} \Theta$

artikel dengan akses terbuka dibawah licenci CC BY-NC-4.0

\section{PENDAHULUAN}

Pendidikan mempunyai peranan yang sangat penting dalam kemajuan suatu bangsa dan negara, baik negara maju maupun negara berkembang seperti layaknya Indonesia. Diera milenial ini, perkembangan teknologi sangat menunjang segala aktifitas manusia. Termasuk didalamnya teknologi pendidikan, tuntutan masyarakat dan kemajuan teknologi membuat pengelolaan pendidikan tidak mungkin lagi dikelola dengan pola tradisional (Nunuk, 2018). Digitalisasi pendidikan merupakan sebuah keharusan demi menciptakan pembelajaran sesuai konteks pembelajaran abad 21. Teknologi hanya sebuah alat dalam menyampaikan pembelajaran, bukan untuk mendistrupsi eksistensi guru dalam mendidik dan membelajarkan siswa (Habib, 2020).

Perkembangan teknologi merupakan tantangan dalam peningkatan kualitas pendidikan di Indonesia mengingat tidak semua orang dapat menggunakan secara maksimal teknologi. Teknologi dapat membantu proses pembelajaran di sekolah baik sebagai sarana maupun sumber belajar bagi guru dan siswa.

Undang - undang No. 14 tahun 2005 tentang guru dan dosen misalnya, yang menyatakan bahwa setiap guru harus mampu memanfaatkan teknologi untuk kepentingan penyelenggaraan kegiatan pengembangan yang mendidik. Guru haruslah melek teknologi sehingga dalam mengajar dapat memanfaatkan berbagai teknologi sebagai media atau sumber belajar. Guru diharapkan mampu merancang media pembelajaran yang inovatif, kreatif, efisien dan efektif sehingga dapat meningkatkan keaktifan peserta didik dalam proses belajar (Nurhikmah, 2020).

Pemanfaatan TIK khususnya penggunaan komputer diberbagai bidang dapat meningkatkan kinerja dan kegiatan dilakukan dengan cepat, tepat dan akurat. $\mathrm{Hal}$ tersebut akan meningkatkan produktivitas kerja. Sekolah-sekolah di Indonesia baik sekolah menengah pertama atau sekolah menengah atas dan sekolah menengah kejuruan menjadikan komputer sebagai mata pelajaran wajib termasuk. Rais (2018) sebagai pendidikan kejuruan, SMK dituntut untuk mempersiapkan diri menghadapi era persaingan global agar dapat menghasilkan pekerja yang sangat kompetitif, terampil, dan berkualitas yang relevan dengan tuntutan tempat kerja saat ini. Teknologi komputer memberikan inovasi dalarn proses pembelajaran dan juga memungkinkan proses belajar mengajar jarak jauh atau pembelajaran tanpa tatap muka. Inovasi ini diperlukan agar proses pembelajaran menjadi menyenangkan dan menarik. Inovasi bisa berupa pengembangan metode pembelajaran dan media pembelajaran.

PBM di sekolah, guru dituntut agar selalu menyuguhkan inovasi baru dengan harapan siswa mampu mendapatkan pengalarnan baru dalam PBM. Sebaik apa pun sistem pendidikan, kurikulum, fasilitas atau sarana prasarana pembelajaran, jika guru tidak mau memanfatkan media pembelajaran 
dalam proses pembelajaran maka sangat sulit untuk mendapatkan hasil yang maksimal. Metode dan media pembelajaran yang menarik akan membantu guru untuk meningkatkan motivasi serta pemahaman siswa dalam menyerap materi pelajaran. Namun, kenyataannya tidak semua guru mampu mengembangkan media pembelajaran.

Media pembelajaran yang digunakan dapat membantu guru dalam menyampaikan materi yang diajarkan serta membantu siswa dalam memahami materi yang dipelajarinya. Kurangnya pemanfaatan media berbasis multimedia interaktif disekolah, guru masih mendominasi proses pembelajaran, sehinga proses pembelajaran cenderung membosankan dan membuat siswa bersifat pasif. Permasalahan yang terjadi sehingga banyak siswa mendapatkan nilai dibawah nilai KKM atau nilai yang masih standar salah satu penyebabnya adalah penggunaan model pembelajaran yang masih konvensional. Model pembelajaran konvensional dapat menimbulkan rasa bosan yang menyebabkan berkurangnya motivasi belajar dalam diri siswa.

Pattaufi (2019) proses belajar mengajar yang efektif memerlukan suatu media yang sesuai dengan karakter siswa, mata pelajaran yang disampaikan, suasana dan prasarana penunjang. Perangkat pembelajaran yang baik akan menuntun siswa untuk meningkatkan hasil belajar dengan baik begitupun sebaliknya. Inilah yang menjadi alasan peneliti tertarik untuk meneliti tentang Pengembangan multimedia interaktif dalam pembelajaran simulasi dan komunikasi digital kelas X di SMK Muhammadiyah Sidenreng Rappang.

\section{METODE}

Tabel 1. Kategori validasi analisis persentase produk

\begin{tabular}{clll}
\hline No & $\begin{array}{c}\text { Tingkat } \\
\text { pencapaian }\end{array}$ & \multicolumn{1}{c}{ Kualifikasi } & \multicolumn{1}{c}{ Keterangan } \\
\hline 1 & $81-100 \%$ & Sangat baik & Sangat valid, tidak perlu direvisi \\
2 & $61-80 \%$ & Baik & Valid, tidak perlu direvisi \\
3 & $41-60 \%$ & Cukup baik & Cukup valid, perlu direvisi \\
4 & $21-40 \%$ & Kurang baik & Tidak valid, perlu direvisi \\
5 & $<20 \%$ & Sangat kurang baik & Sangat tidak valid, perlu direvisi \\
\hline
\end{tabular}

Sumber: Arikunto, (2016).

Sementara untuk menentukan tingkat

kepraktisan, siswa dan guru sebagai
Jenis penelitian ini adalah penelitian dan pengembangan (R\&D) dengan model pengembangan ADDIE. Subjek penelitian terdiri dari ahli materi, ahli media, siswa dan guru mata pelajaran simulasi dan komunikasi digital kelas X SMK Muhammadiyah Sidenreng Rappang. Teknik pengumpulan data wawancara, angket, dan tes.

Proses validasi dilakukan untuk memperoleh nilai mengenai tingkat kevalidan produk multimedia interaktif yang dikembangkan oleh 2 ahli yakni ahli materi dan ahli media, setelah itu tahap selanjutnya yaitu melakukan uji coba perorangan, uji coba kelompok kecil, dan uji tanggapan guru untuk mengetahui tingkat kepraktisan produk. Uji coba kelompok besar dilakukan untuk mengukur tingkat keefektivan produk yang telah dikembangkan.

Data yang diperoleh dalam penelitian ini adalah data kualitatif dan kuantitatif. Data kualitatif diperoleh dari kritik dan saran. Data tersebut digunakan dalam proses perbaikan dan penyempurnaan produk. Sementara untuk data kuantitatif diperoleh dari skor dalam angket. Teknik analisis data kuantitatif yang digunakan dalam penelitian ini adalah deskriptif kuantitatif. Data yang dianalisis meliputi kevalidan media dari ahli materi, ahli media, dan respon yang diberikan guru dan siswa sebagai objek uji coba.

Seluruh data yang didapatkan dari validator dan responden dianalisis menggunakan teknik deskriptif presentase menggunakan rumus sebagai berikut:

Persentase $=\frac{\sum(\text { jawaban } \times \text { bobot tiap pilihan })}{n \times \text { bobot tertinggi }} \times 100 \%$

Sumber: Arismunandar, (2015)

Untuk menetukan tingkat kevalidan media pembelajaran yang dikembangkan, digunakan kriteria kualifikasi penilaian berdasarkan sebagai berikut ini: Sangat tidak valid, perlu direvisi

responden terlibat langsung dalam proses uji coba multimedia interaktif. Partisipasi 
151 Indonesia Journal of Learning Education and Counseling

diperlukan dari responden untuk mendapatkan data yang dapat digunakan sebagai dasar untuk menetapkan tingkat kepraktisan. Pada uji coba produk terdiri dari tiga tahap yaitu uji coba perorangan, uji coba kelompok kecil, dan uji tanggapan guru mata pelajaran simulasi dan komunikasi digital.

Untuk menetukan tingkat kepraktisan produk yang dikembangkan, digunakan kriteria kualifikasi penilaian sebagai berikut ini:

Tabel 2. Rentang persentase dan kriteria produk

\begin{tabular}{cll}
\hline No & Rentang persentase (\%) & Kategori \\
\hline 1 & $81,00 \%-100,00 \%$ & Sangat praktis \\
2 & $61,00 \%-80,00 \%$ & Praktis \\
3 & $41,00 \%-60,00 \%$ & Cukup praktis \\
4 & $21,00 \%-40,00 \%$ & Kurang praktis \\
5 & $00,00 \%-20,00 \%$ & Tidak praktis \\
\hline
\end{tabular}

Sumber: Akbar (2017)

Tingkat keefektifan dapat dilihat dari hasil belajar siswa, dimana hasil belajar mengalami peningkatan dari pre-test ke post-test dan nilai yang dicapai tersebut berada di atas KKM yakni 75.

\section{HASIL DAN PEMBAHASAN}

Penelitian pengembangan multimedia interaktif dalam pembelajaran simulasi dan komunikasi digital ini, menggunakan jenis penelitian dan pengembangan (Research and Development) dengan menggunakan model ADDIE yang bertujuan untuk menghasilkan media pembelajaran berupa multimedia interaktif dalam pembelajaran simulasi dan komunikasi digital yang memenuhi syarat validitas, praktis, dan efektif.

\section{Gambaran tingkat kebutuhan}

Kebutuhan siswa akan media dapat diketahui melalui hasil analisis yang dilakukan. Analisis yang digunakan sebagai acuan pengembangan produk multimedia interaktif dalam pembelajaran simulasi dan komunikasi digital khususnya pada materi presentasi video dilakukan oleh pengembang untuk mengumpulkan data - data yang dibutuhkan dalam pengembangan multimedia interaktif. Pada tahap ini peneliti menganalisa 3 hal yakni; analisis kebutuhan, analisis kurikulum serta analisis karakteristik siswa.

Analisis kebutuhan dilakukan saat observasi di sekolah dengan melakukan identifikasi terhadap keadaaan bahan ajar berupa materi pembelajaran. Proses pembelajaran masih cenderung menggunaan metode pembelajaran konvensional. Hal ini berdasarkan pengamatan diperoleh informasi sebagai berikut: (1) Dari segi tenaga pengajar, guru yang ada di SMK Muhammadiyah Sidenreng Rappang juga belum mampu berkreasi secara maksimal. Pembelajaran dilakukan oleh guru dengan menggunakan metode ceramah yang mengakibatkan siswa lebih banyak pasif, akibatnya beberapa siswa terkadang merasa jenuh dan hanya beberapa siswa yang terlibat aktif dalam pembelajaran, (2) materi pembelajaran yang dikemas belum maksimal karena masih berpatokan pada satu buku sehingga pembelajaran terkesan monoton, dan (3) minimnya sarana yang tersedia seperti belum adanya kamera, lightstand, background dan komponen lainnya juga menjadi permasalahan utama sehingga pembelajaran simulasi dan komunikasi digital materi presentasi video sulit tercapai di dalam kelas.

Hasil analisis kurikulum yang dilakukan peneliti menunjukkan bahwa SMK Muhammadiyah Sidenreng Rappang menggunakan kurikulum 2013. Siswa kelas X umumnya berumur 15-16 tahun. Anak usia tersebut berada pada tahap operasional formal. Tahap operasional formal adalah periode terakhir perkembangan kognitif. Tahap ini akan dialami pada usia 11 tahun dan berlanjut hingga dewasa. Pada tahap ini anak mampu berpikir abstrak, serta menalar secara logis, dan menarik sebuah kesimpulan dari informasi yang tersedia. Sesuai dengan 
perkembangan zaman yang sangat pesat seperti saat sekarang ini, tentunya siswa lebih tertarik untuk menerapkan media baru dalam proses pembelajaran. Dengan adanya inovasi pengembangan sebuah media yang terkesan baru menurut mereka, sangat membantu dan menarik perhatian mereka untuk belajar.

Multimedia interaktif ini diharapkan dapat membantu siswa dan guru dalam proses pembelajaran karena terdapat tampilan yang dapat melibatkan beberapa indra siswa, karena media pembelajaran yang banyak melibatkan anggota tubuh yang dalam proses pembelajaran, maka tingkat kompetensi yang didapatkan oleh peserta didik juga semakin banyak pula (Hafsah, 2016). Multimedia interaktif juga membantu guru dalam proses penyampaian materi pelajaran, sehingga siswa tidak lagi merasa bosan dan jenuh akan pelajaran simulasi dan komunikasi digital. Multimedia interaktif juga bisa meminimalisir kekurangan sarana seperti belum adanya kamera atau lightstand yang di sekolah.

Penggunaan multimedia interaktif dalam proses pembelajaran berpengaruh positif terhadap hasil belajar siswa yang meningkat dan memberi manfaat positif bagi siswa untuk belajar mandiri, karena tidak hanya mendengarkan tetapi siswa dapat mengamati serta memperhatikan gambar secara langsung, dan mendengarkan audio yang menarik perhatian siswa, sehingga siswa termotivasi untuk mengikuti pelajaran simulasi dan komunikasi digital dengan baik. (Hamalik dalam Arsyad 2017) media pembelajaran yang digunakan dalam proses pembelajaran dapat meningkatkan keinginan dan minat yang baru, membangkitkan motivasi dan rangsangan kegiatan belajar siswa. Dari segi kebutuhan tersebut dan didukung beberapa pendapat ahli serta bukti empirisnya maka diketahui tingkat kebutuhan pengembangan multimedia interaktif dalam pembelajaran simulasi dan komunikasi digital kelas X di SMK Muhammadiyah Sidenreng Rappang.

Hasil analisis kebutuhan, kurikulum, dan karakter siswa tersebut dapat disimpulkan bahwa siswa memerlukan media yang dapat merangsang dan membangkitkan semangat belajar dan sebagai salah satu alternatif sumber belajar yang dapat digunakan secara individu ataupun berkelompok.

\section{Uji kevalidan produk}

Validasi atau penilaian melibatkan seorang validator ahli materi dan seorang ahli media. Validator ahli isi/materi adalah seorang pakar yang mengetahui mengenai pelajaran simulasi dan komunikasi digital di SMK sedangkan validator ahli media merupakan prasyarat sebelum diuji coba kepada pengguna multimedia interaktif presentasi video yang dikembangkan, validasi ahli media ini yang akan menilai aspek tampilan dan aspek pemrograman yang ada pada multimedia interaktif presentasi video. Validasi oleh ahli materi pembelajaran untuk mengetahui kevalidan materi dari segi isi dan materi. Sedangkan validasi media pembelajaran dilakukan oleh ahli media untuk mengetahui kevalidan media dari segi tampilan dan program media.

Uji validasi materi multimedia interaktif dalam pembelajaran simulasi dan komunikasi digital oleh seorang ahli isi/materi pelajaran diperoleh skor 43 dengan presentase $95 \%$ (tingkat pencapaian $81 \%$ $100 \%$ ) Hasil validasi ahli materi menunjukkan bahwa pada aspek kesesuaian materi dengan RPP, relevansi materi dengan tujuan pembelajaran, ketepatan judul dengan isi materi, kejelasan materi, kesesuaian antara gambar /ilustrasi dan materi, membantu dalam pembelajaran, dan mempermudah pemahaman siswa memperoleh penilaian sangat baik, sementara pada kelengkapan materi dan kemudahan operasional memperoleh penilain baik. Sehingga saat hasil penilaian dari ahli materi ditotal dan dikonversikan dengan tabel konversi, persentase tingkat pencapaian berada pada kualifikasi sangat baik, serta berdasarkan kesimpulan validator, materi yang terdapat pada multimedia interaktif dapat digunakan atau diuji cobakan tanpa perlu direvisi.

Uji validasi media pembelajaran multimedia interaktif dalam pembelajaran simulasi dan komunikasi digital oleh ahli media diperoleh persentase tingkat pencapaian $74 \%$, berada pada kualifikasi baik dan valid, dengan melakukan revisi terlebih dahulu sesuai dengan saran dari validator sebelum dilanjutkan pada tahap selanjutnya. Hasil validasi ahli media menunjukkan bahwa pada aspek tampilan yang terdiri dari ketepatan pemilihan background dengan materi, ketepatan proporsi layout, kemenarikan cover depan memperoleh penilaian sangat baik. Sementara pada 
kemenarikan animasi dan kesesuaian tampilan dengan isi memperoleh penilaian baik, sedangkan pada ketepatan pemilihan font agar mudah dibaca, ketepatan pemilihan background dengan materi, ketepatan proporsi layout, ketepatan pemilihan font agar mudah dibaca, ketepatan ukuran huruf agar mudah dibaca, ketepatan warna teks agar mudah dibaca, komposisi gambar, kualitas tampilan gambar, kesesuaian animasi dengan materi, ketepatan pemilihan backsound dengan materi, ketepatan pilihan video dengan materi, kualitas video memperoleh penilaian cukup dari ahli media. Dari segi aspek program kesesuaian dengan pengguna dan fleksibilitas (dapat digunakan mandiri dan terbimbing) memperoleh nilai sangat baik. Akan tetapi pada tampilan petunjuk evaluasi, menyajikan tolak ukur keberhasilan, ketepatan penggunaan tombol navigasi, ketepatan kinerja interactive link memperoleh nilai cukup dari ahli media. Dari hasil penilaian tersebut, seluruh penilaian ditotal dan dikonversikan dengan tabel konversi, persentase tingkat pencapaian berada pada kualifikasi baik namun perlu dilakukan beberapa revisi terlebih dahulu sesuai dengan saran dari validator seperti cantumkan sumber, tambahkan petunjuk mengerjakan soal, tambahkan soal evaluasi, perbaiki link yang error, serta tambahkan kunci jawaban dan pembahasan.

Setelah produk multimedia interaktif direvisi sesuai dengan saran dari validator ahli media, diperoleh hasil penilaian dari validator media pembelajaran dengan total skor 96 . Selanjutnya nilai tersebut diubah kedalam persentase dan mendapatkan skor $96 \%$.

Hasil validasi ahli materi menunjukkan bahwa pada aspek tampilan seperti ketepatan pemilihan background dengan materi, ketepatan proporsi layout, ketepatan pemilihan font agar mudah dibaca, ketepatan ukuran huruf agar mudah dibaca, ketepatan warna teks agar mudah dibaca, kesesuaian animasi dengan materi, ketepatan pemilihan backsound dengan materi, ketepatan pilihan video dengan materi, kualitas video, kemenarikan cover depan memperoleh penilaian sangat baik oleh ahli media. Sementara pada komposisi gambar, kualitas tampilan gambar, kemenarikan animasi, kesesuaian tampilan dengan isi memperoleh penilaian baik oleh ahli media. Sedangkan pada aspek program seperti kesesuaian dengan pengguna, fleksibilitas (dapat digunakan mandiri dan terbimbing), tampilan petunjuk evaluasi, menyajikan tolak ukur keberhasilan, ketepatan penggunaan tombol navigasi, ketepatan kinerja interactive link semuanya memperoleh penilaian sangat baik. Dari hasil penilaian tersebut kemudian dikonversikan dengan tabel konversi, persentase tingkat pencapaian berada pada kualifikasi sangat baik yang artinya produk multimedia interaktif sangat valid, tidak perlu direvisi sehingga bisa untuk dilanjutkan pada tahap selanjutnya.

\section{Uji kepraktisan produk}

Uji coba pengguna yang terdiri dari 3 tahap pengujian yaitu uji coba perorangan dan kelompok kecil, serta uji tanggapan guru mata pelajaran. Siswa dan guru sebagai responden terlibat langsung dalam proses uji coba produk. Partisipasi diperlukan dari responden untuk mendapatkan data yang akan digunakan sebagai dasar untuk menetapkan tingkat kepraktisan.

Untuk uji coba perorangan secara keseluruhan memperoleh rata-rata persentase sebesar 98,6\% dan berada pada kategori sangat praktis, sehingga tidak perlu direvisi dan multimedia interaktif tersebut dapat dilanjutkan ke tahap berikutnya.

Hasil penilaian melalui angket pada uji coba kelompok kecil memperoleh rata-rata persentase $92 \%$ dengan kategori sangat praktis sehingga bisa dilanjutkan pada tahap selanjutnya. Setelah melewati tahap uji coba kelompok kecil, selanjutnya produk diujicoba berdasarkan tanggapan dari guru mata pelajaran. Rata-rata persentase yang diperoleh dari tanggapan guru mata pelajaran simulasi dan komunikasi digital mencapai 100\% menunjukkan bahwa media berada pada kategori sangat praktis.

Berdasarkan hasil respon yang telah didapatkan dari siswa dan guru terhadap multimedia interaktif yang dikembangkan, dapat disimpulkan bahwa multimedia interaktif dalam pembelajaran simulasi dan komunikasi digital yang dikembangkan memenuhi kriteria kepraktisan untuk digunakan dalam proses belajar mengajar di dalam kelas.

\section{Uji keefektivan produk}

Hasil analisis tes hasil belajar menunjukan bahwa rata-rata skor atau hasil belajar pada pre-test 70,2 dan rata-rata skor atau nilai pada post-test yakni 84,3 . Hal ini 
berarti bahwa multimedia interaktif yang dikembangkan memenuhi kriteria keefektifan sehingga layak untuk digunakan dalam proses belajar mengajar di dalam kelas.

\section{Pembahasan}

Hasil pengembangan ditinjau dari hasil uji validitas, kepraktisan, dan keefektifan produk multimedia interaktif ini sangat mudah digunakan oleh guru dan peserta didik serta dapat membantu guru dan siswa dalam menjelaskan dan memahami materi pembelajaran.

Hal ini didukung oleh pendapat Musyaffak (2014) bahwa: media pembelajaran yang memuat konten multimedia didalamnya, yaitu berupa gambar, video, animasi, text, dan audio sangat bermanfaat bagi peserta didik, karena sangat memudahkan dan membantu dalam proses pembelajaran.

Hasil dari penelitian ini sejalan dengan hasil penelitian terdahulu yang dilakukan oleh Baharuddin (2015) dengan judul Pengembangan Media Pembelajaran Berbasis Multimedia Interaktif Sekolah Menengah Kejuruan terhadap Efektif dan Efisiensi Pembelajaran memperoleh hasil multimedia pembelajaran interaktif yang dikembangkan layak dan efektif digunakan sebagai media pembelajaran khususnya pada mata diklat memasang instalasi penerangan bangunan sederhana juga dapat meningkatkan keterampilan guru dalam membuat suatu pembelajaran yang lebih menarik bagi siswa. Sehingga siswa lebih tertarik lagi dalam belajar, dikarenakan mereka belajar dengan cara yang lebih menarik. Multimedia interaktif memudahkan guru dalam menjelaskan materi pelajaran kepada peserta didik sehingga tercipta proses pembelajaran yang tidak berpusat pada guru melainkan pada peserta didik yang aktif dalam pembelajaran. Keberhasilan multimedia interaktif ini didukung oleh pendapat Munir (2015) tentang kelebihan multimedia interaktif dalam pembelajaran yaitu sistem pembelajaran lebih inovatif dan interaktif, pendidik akan kreatif inovatif, menambah motivasi siswa, mampu memvisualisasikan materi, peserta didik lebih mandiri.

Penelitian dan pengembangan multimedia interaktif dalam pembelajaran simulasi dan komunikasi digital kelas $\mathrm{X}$ di
SMK Muhammadiyah Sidenreng Rappang mendapatkan hasil yang maksimal terhadap kualitas media pembelajaran yang meliputi valid, praktis dan efektif sehingga layak untuk dikembangkan dan digunakan dalam proses pembelajaran simulasi dan komunikasi digital.

\section{SIMPULAN DAN SARAN}

Berdasarkan pada proses pengembangan sehingga dapat disimpulkan bahwa produk multimedia interaktif adalah (1) Tingkat kebutuhan akan multimedia interaktif dalam pembelajaran simulasi dan komunikasi digital kelas $\mathrm{X}$ di SMK Muhammadiyah Sidenreng Rappang sangat tinggi. Hal tersebut dibuktikan dengan nilai hasil belajar siswa yang telah mencapai KKM setelah menggunakan multimedia interaktif; (2) Hasil analisis data validasi multimedia interaktif dalam pembelajaran simulasi dan komunikasi digital berada pada kategori sangat valid, ini diperoleh dari penilaian validasi ahli materi dan media; (3) Hasil penilaian responden melalui uji coba perorangan, uji coba kelompok kecil, dan uji tanggapan guru mata pelajaran simulasi dan komunikasi digital terhadap produk multimedia interaktif dinyatakan sangat praktis; (4) Multimedia interaktif dalam pembelajaran simulasi dan komunikasi digital yang dikembangkan efektif dilihat dari ratarata rekapitulasi penilaian hasil belajar menunjukakan adanya peningkatan skor tes belajar seluruh siswa sudah diatas nilai KKM.

Dari hasil peneliotian disarankan: (1) Multimedia interaktif dalam pembelajaran simulasi dan komunikasi digital yang telah dikembangkan ini valid, praktis, dan efektif di SMK Muhammadiyah Sidenreng Rappang, sehingga disarankan untuk digunakan ke sekolah SMK kelas X lainnya. Karena multimedia interaktif ini baik digunakan dalam proses belajar mengajar di kelas maupun membantu peserta didik belajar secara mandiri; (2) Objek penelitian ini adalah siswa SMK Muhammadiyah Sidenreng Rappang dan terbatas hanya ada pada salah satu mata pelajaran. Hasil penelitian ini belum tentu sama jika diberlakukan pada siswa sekolah lain. Oleh karena itu disarankan kepada para peneliti kiranya dapat melaksanakan penelitian lanjutan dengan lokasi berbeda dengan materi 
yang sama atau pada siswa yang berbeda dengan materi yang berbeda atau sebaliknya. Sehingga hasil penelitian tentang proses pembelajaran dan hasil belajar semakin bervariasi; (3) Perlunya peningkatan mutu pendidikan salah satunya dengan pemberdayaan para teknolog pendidikan di sekolah-sekolah maupun di instansi terkait pendidikan. Guna untuk membantu dalam pengembangan multimedia interaktif dalam pembelajaran.

\section{DAFTAR RUJUKAN}

Akbar, Sa'dun. 2017. Instrumen Perangkat Pembelajaran cetakan kelima. Bandung: PT Remaja Rosdakarya.

Arikunto, S. 2016. Prosedur Penelitian Suatu Pendekatan Praktik. Jakarta: Rineka Cipta.

Arismunandar, Nurhikmah H. 2015. Pengembangan Model Pelatihan Mbs Bagi Kepala Sekolah. Proceeding. Scientific Forum-Faculty of Education Departement of Science Education (FIP-JIP) and The International Seminar.

Arsyad, Azhar. 2017. Media Pembelajaran. Jakarta : Raja Grafindo Persada.

Habib, Ahmad. 2020., Media Pembelajaran Abad 21: Kebutuhan Multimedia Interaktif Bagi Guru dan Siswa Sekolah Dasar. Jurnal Riset Teknologi dan Inovasi Pendidikan . p-ISSN: 26224763 | e-ISSN: 2622-2159 | Vol. 3, No. 1, Januari 2020, Hal. 25-35.

Hafsah, dkk. 2016. Penerapan Media Pembelajaran Modul Elektronik untuk Meningkatkan Hasil Belajar Siswa pada Mata Pelajaran Teknologi Mekanik. Journal of Mechanical Engineering Education, Vol. 3, No. 1, Juni 2016 hal.107.
Musyaffak, Ahmad. 2014. Cara Aktif Membuat CD Interaktif. Jakarta: PT Elex Media Komputindo.

Nunuk, S., Setiawan, A., Aditin, \& Putria. 2018. Media Pembelajaran Inovasi dan Pengembangannya. Bandung: PT. Remaja Rosdakarya.

Nurhikmah H. \& Abd. Haling. 2020. Peningkatan kompetensi guru melalui pelatihan media video di Kabupaten Sinjai. Prosiding Seminar Nasional Lembaga Penelitian dan Pengabdian Kepada Masyarakat Universitas Negeri Makassar. ISBN: 978-623-7496-01-4.

Pattaufi, Arnidah. 2019. Pengaruh Pemanfaatan Bahan Ajar Berbasis Audio-Visual (Video) pada Mata Pelajaran Sejarah Kelas X di SMA Negeri 11 Pangkep. PROSIDING SEMINAR NASIONAL LP2M UNM. "Peran Penelitian dalam Menunjang Percepatan Pembangunan Berkelanjutan di Indonesia". ISBN: 978-623-7496-144 .

Rais, Muhammad. 2018. Skill Competency Test Model (UKK) Graduates of Partnership-Based Vocational High School: Preparing Graduates Facing the Fourth Industrial Revolution. International Conference on Indonesian Technical Vocational Education and Association (APTEKINDO 2018). Advances in Social Science, Education and Humanities Research (ASSEHR), volume 201. 